\title{
Spectroscopic and analytical studies of lead mixed cadmium oxalate crystals
}

\author{
Ganavi A. S., ${ }^{1}$ Dharmaprakash S. M., ${ }^{1 *}$ Jagannatha N., ${ }^{2}$ Nagaraja K. P. ${ }^{2}$ and Delma D 'Souza ${ }^{2}$ \\ ${ }^{1}$ Department of Physics, Mangalore University, Mangalore-574199 \\ ${ }^{2}$ Post graduate department of Physics, FMKMC College (A constituent college of Mangalore University), \\ Madikeri-571201
}

E-mailID:smdharma@yahoo.com,ganavi.amemane@gmail.com

\begin{abstract}
Lead mixed cadmium oxalate (LMCO) crystals were grown in oxalic acid impregnated silica hydro gel. Optimal growth condition was established by varying specific gravity of sodium meta silicate (SMS), gel $\mathrm{pH}$, gel temperature and concentration of reactant solutions. The grown crystals were found to be transparent, hard and water insoluble. The LMCO crystals were characterized in succession by Energy dispersive X-ray (EDX) spectroscopy, Fourier transform infrared (FTIR) spectral technique, Thermogravimetric analysis (TGA), Powder X-ray diffraction (P-XRD) and UV-visible spectroscopy. Occupation of lead $\left(\mathrm{Pb}^{2+}\right)$ ions in the vacancies of cadmium $\left(\mathrm{Cd}^{2+}\right)$ ions was confirmed by EDX. FTIR spectrum identified the presence of oxalate $\left(\mathrm{C}_{2} \mathrm{O}_{4}\right)^{2-}$ ions and metal-oxygen linkage in the novel crystals. TG analysis betrayed the stable oxide state of LMCO crystals after decomposition. P-XRD pattern depicted the high crystallinity. Optical studies revealed the insulating behaviour of the grown crystals.
\end{abstract}

Keywords: EDX, FTIR, insulator, oxalate crystals

\section{Introduction}

Crystal growth is a trust area of research, fascinated by many investigators [1]. As per the literature, mixed crystals find their applications in opto-electronics. Studies on crystal growth in gel media unveil inherent physical and chemical properties of oxalate crystals. Modern day science and technology requires fabrication of high-quality defect free semiconductors, electrical components and optical devices [2]. Gel technique is the established tool, with the aid of that variety of pure, doped, co-doped and mixed crystals are grown. Crystals grown in gel are water insoluble, possess special dielectric properties and exhibit outstanding thermal stability. The investigation propounded by us deals with the growth of lead mixed cadmium oxalate (LMCO) crystals in oxalic acid impregnated silica (OIS) hydro gel and its characterization. 


\section{Materials and methods}

\subsection{Growth of Lead mixed cadmium oxalate crystals}

Single test tube gel diffusion method was employed to grow LMCO crystals in oxalic acid impregnated silica (OIS) hydro gel. Chemicals used were sodium meta silicate $\left(\mathrm{Na}_{2} \mathrm{SiO}_{3}\right)$, oxalic acid $\left(\mathrm{C}_{2} \mathrm{H}_{2} \mathrm{O}_{4} \cdot 2 \mathrm{H}_{2} \mathrm{O}\right)$, cadmium nitrate $\left(\mathrm{Cd}\left(\mathrm{NO}_{3}\right)_{2} 4 \mathrm{H}_{2} \mathrm{O}\right)$ and lead nitrate $\left(\mathrm{Pb}\left(\mathrm{NO}_{3}\right)_{2}\right)$ of $\mathrm{AR}$ grade.

Growth of LMCO crystal required optimization of gel media. OIS gel was accomplished by mixing oxalic acid $(0.75 \mathrm{M})$ with sodium meta silicate (SMS) solution of specific gravity $1.0375 \mathrm{~g} / \mathrm{cm}^{3}$ in $5: 4$ ratio and allowed to set for gelling. After 8 days, above the set gel the reactant mixture of $\mathrm{Cd}\left(\mathrm{NO}_{3}\right)_{2}(0.5 \mathrm{M})$ and $\mathrm{Pb}\left(\mathrm{NO}_{3}\right)_{2}(0.5 \mathrm{M})$ in the ratio $3: 3$ added slowly by sideways of the test tube. Reagent cations diffused through the set gel, nucleated with oxalate ions which initiated crystallization. Crystal growth accomplished in 10 days for LMCO crystals and grown crystals were extracted and further subjected to characterization. The chemical process which describe the formation of LMCO crystals is as follows:

$\mathrm{Pb}^{2+}+\mathrm{Cd}\left(\mathrm{NO}_{3}\right)_{2} \cdot 4 \mathrm{H}_{2} \mathrm{O}+\mathrm{C}_{2} \mathrm{H}_{2} \mathrm{O}_{4} \cdot 2 \mathrm{H}_{2} \mathrm{O} \longrightarrow \mathrm{Cd}: \mathrm{Pb}\left(\mathrm{C}_{2} \mathrm{O}_{4}\right) \cdot 3 \mathrm{H}_{2} \mathrm{O}+2 \mathrm{HNO}_{3}+3 \mathrm{H}_{2} \mathrm{O}$

Fig. 1 illuminates the growth phase and extracted LMCO crystals. The optimized growth parameters are recorded in Table 1.

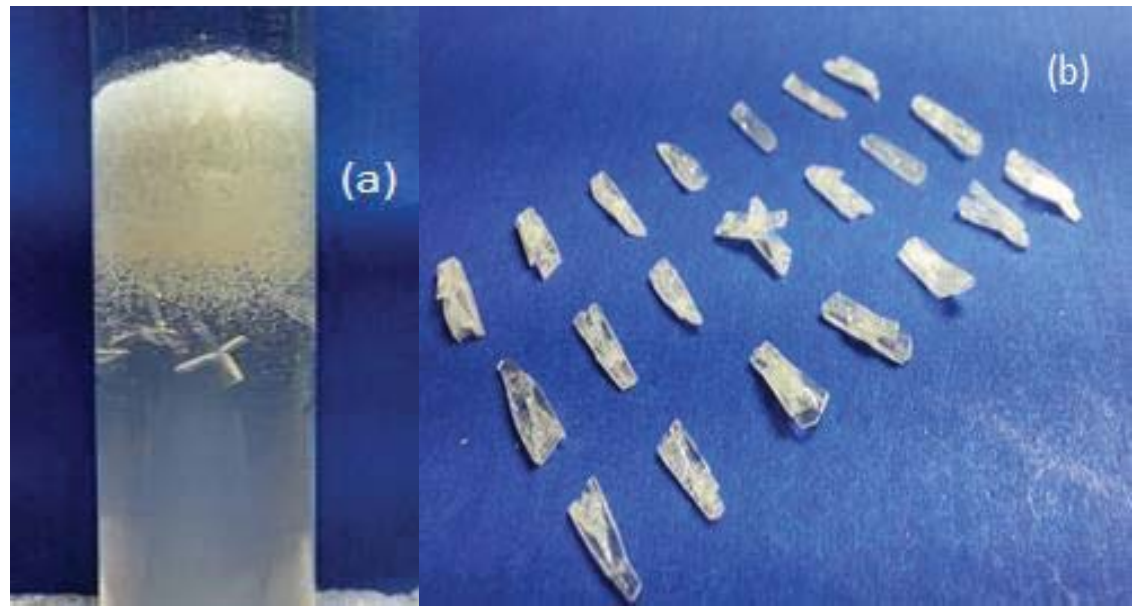

FIG 1. LMCO crystals - (a) Growth in silica gel and (b) extracted crystals.

Table 1. Optimal growth conditions of LMCO crystals.

\begin{tabular}{|l|l|}
\hline Growth parameters & Optimum conditions \\
\hline Specific gravity of SMS solution & $1.0375 \mathrm{~g} / \mathrm{cm}^{3}$ \\
\hline Concentration of oxalic acid & $0.75 \mathrm{M}$ \\
\hline Ratio of SMS : Oxalic acid & $5: 4$ \\
\hline pH of the gel & 1.5 \\
\hline Temperature & $20.5^{\circ} \mathrm{C}$ \\
\hline Time to set gel & 8 days \\
\hline
\end{tabular}

2 INTERNATIONAL JOURNAL OF INNOVATIVE RESEARCH IN PHYSICS 


\begin{tabular}{|l|l|}
\hline Concentration of supernatant solutions & $0.5 \mathrm{M}$ \\
\hline Ratio of cationic reactants & $3: 3$ \\
\hline Duration of crystal growth & 10 days \\
\hline Physical appearance & transparent and hard \\
\hline
\end{tabular}

\subsection{Characterization}

Chemical composition of LMCO crystal were determined using CARL ZEISS FESEM attached with EDS system (Oxford instruments). Bruker (Alpha) KBr Fourier Transform Infrared Spectrophotometer (FTIR) (400-4000 $\mathrm{cm}^{-1}$ ) was used to identify the functional group associated with the grown crystals. Thermogravimetric analysis was studied using TGA-DSC (Hitachi STA 7300). Powder X-ray diffracted pattern was obtained using Bruker D8 Advance Twin-Twin diffractometer. UV-visible spectrum was obtained with the aid of UV VIS NIR $\theta / 2 \theta$ spectrophotometer (HO-SPA-1990P).

\section{Result and discussions}

In-depth characterization of LMCO crystal using Energy dispersive X-ray (EDX) measurements identified the characteristic peaks of cadmium, lead, oxygen and carbon in the EDX spectrum (Fig. 2) The mixed crystal exhibited a cationic distribution of $36.04: 1\left(\mathrm{Cd}^{2+}: \mathrm{Pb}^{2+}\right)$ and brought up as a good mixed crystal. The SEM image at $100 \mu \mathrm{m}$ resolution (Fig. 3) show layered deposition with valley regions. The weight and atomic percentages of elements are listed in Table 2.

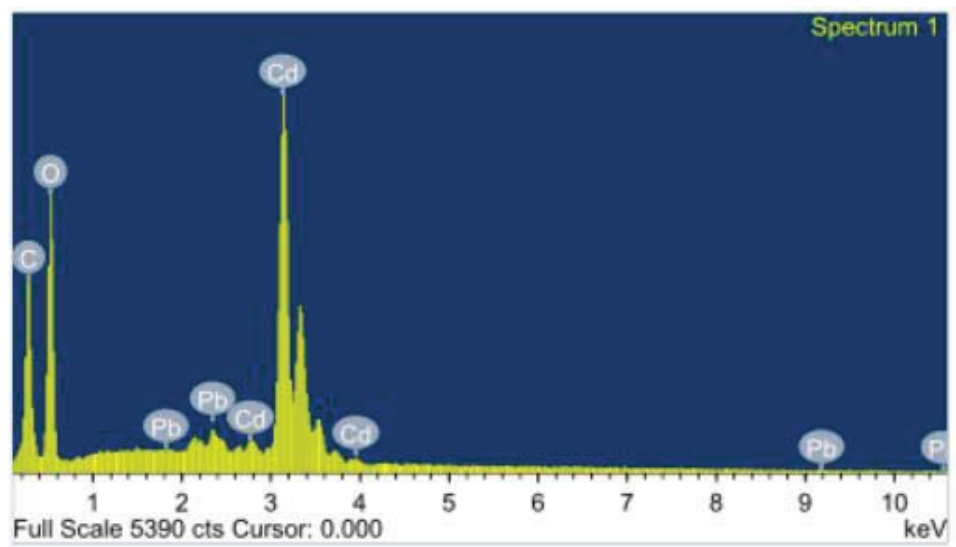

FIG 2. EDX spectrum - LMCO crystals. 


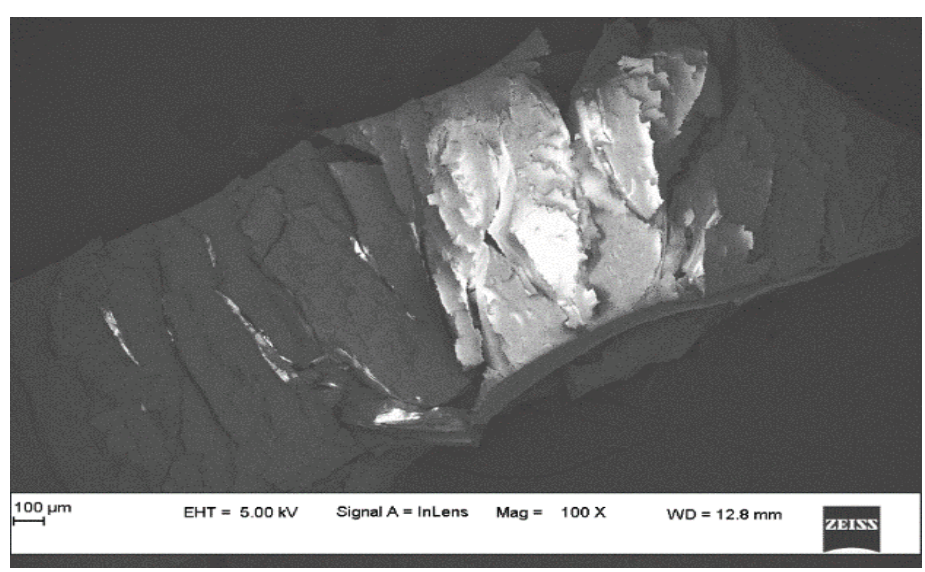

FIG 3. SEM image - LMCO crystal.

Table 2. EDX result of LMCO crystals.

\begin{tabular}{|l|l|l|}
\hline Elements & Weight \% & Atomic $\%$ \\
\hline $\mathrm{Cd}$ & 44.02 & 9.64 \\
\hline $\mathrm{Pb}$ & 2.23 & 0.27 \\
\hline $\mathrm{O}$ & 39.09 & 60.06 \\
\hline $\mathrm{C}$ & 14.66 & 30.03 \\
\hline Total & 100 & 100 \\
\hline
\end{tabular}

Fig. 4 show the Fourier transform infrared (FTIR) spectrum of LMCO crystal. The possible stretching, bending vibrations and corresponding band assignments were recorded in Table 3 [3,4]. LMCO crystal armature consisted of $\mathrm{C}=\mathrm{O}$ stretching (sharp absorption band at $1581.63 \mathrm{~cm}^{-1}$ ), $\mathrm{C}-\mathrm{C}$ vibrations and $\mathrm{C}-\mathrm{O}$ stretching (sharp intense peak at $1311.59 \mathrm{~cm}^{-1}$ ), $\mathrm{OH}$ group with broad absorption band and finger print region constituting $\mathrm{M}-\mathrm{O}$ bond $(\mathrm{M}=\mathrm{Cd}, \mathrm{Pb})$ at 603.72 and $513.07 \mathrm{~cm}^{-1}$ respectively. 


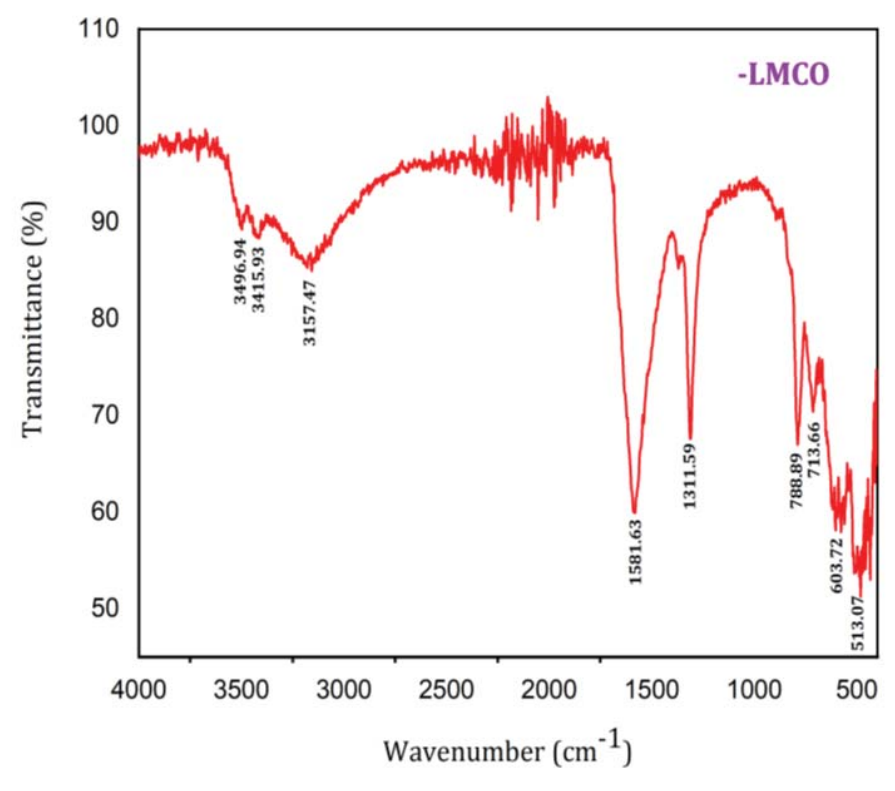

FIG 4. FTIR spectrum - LMCO crystals.

Table 3. FTIR result of LMCO crystals.

\begin{tabular}{|l|l|}
\hline Band assignments & Wavenumbers $\left(\mathrm{cm}^{-1}\right)$ \\
\hline \multirow{2}{*}{ Symmetric and asymmetric stretching of $\mathrm{OH}$ group } & 3496.94 \\
and water of crystallization & 3415.93 \\
& 3157.47 \\
\hline C=O stretching, O-H bending & 1581.63 \\
\hline C-C vibrations, C-O stretching & 1311.59 \\
\hline \multirow{2}{*}{$\mathrm{O}-\mathrm{H}$ out of plane bending } & 788.89 \\
\hline \multirow{2}{*}{$\mathrm{Pb}-\mathrm{O}$ and Cd-O stretching } & 713.66 \\
\hline
\end{tabular}

The decomposition behaviour and thermal stabilities of LMCO crystals were investigated by thermo gravimetric (TG) studies. The TG plots consisted of thermo gravimetric analysis (TGA), derivative thermo gravimetry (DTG) and differential scanning calorimetry (DSC) curves as shown in Fig. 5. The TGA studies determined the degradation temperatures, matter released, rate of weight loss (\%) and chemical process involved during decomposition of LMCO crystals (Table 4). Fig 5(a) show two structural phase transformation. In the first phase of decomposition $\left(\mathrm{T}_{\mathrm{D}}=48.70-181.53^{\circ} \mathrm{C}\right)$ the crystal lost three molecules of crystalline water showed a weight loss of $20.04 \%$ (observed) (calculated $=21.03 \%$ ). In the second phase of decomposition $\left(\mathrm{T}_{\mathrm{D}}=278.80-372.33^{\circ} \mathrm{C}\right) \mathrm{LMCO}$ crystal lost carbon monoxide and carbon dioxide showed a weight loss of $28.1 \%$ (observed) (calculated $=28.02 \%$ ) [5]. The crystal remained stable in oxide state until $1190^{\circ} \mathrm{C}$, above which the crystal decomposed completely $\left(\mathrm{T}_{\mathrm{DTG}}=1274^{\circ} \mathrm{C}\right)$. The first $\left(\mathrm{T}_{\mathrm{DTG}}=\right.$ $135^{\circ} \mathrm{C}$ and $\mathrm{T}_{\mathrm{DSC}}=148{ }^{\circ} \mathrm{C}$ endothermic $)$ and second degradation phases $\left(\mathrm{T}_{\mathrm{DTG}}=349^{\circ} \mathrm{C}\right.$ and $\mathrm{T}_{\mathrm{DSC}}=363{ }^{\circ} \mathrm{C}$ exothermic) were confirmed by DTG and DSC peaks. 
Using EDX measurements followed by evaluation from FTIR and TG studies, LMCO crystal propounded with chemical formula $\left(\mathrm{Cd}_{0.973} \mathrm{~Pb}_{0.027}\right) \mathrm{C}_{2} \mathrm{O}_{4} .3 \mathrm{H}_{2} \mathrm{O}$ and molecular weight of 257.03 (Table 5).
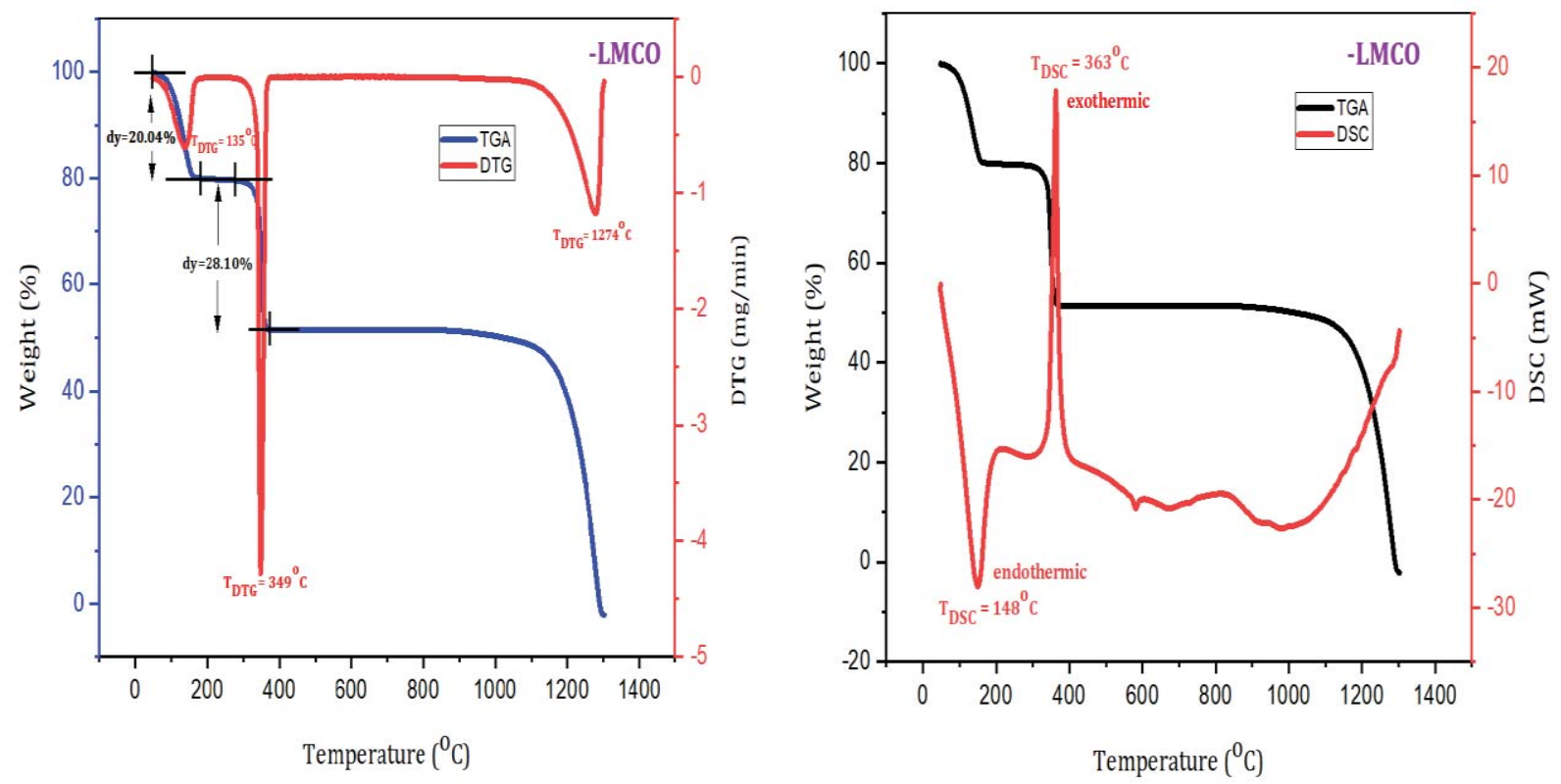

FIG 5. TG plot - LMCO crystals (a) and (b).

Table 4. Decomposition behaviour of LMCO crystals.

\begin{tabular}{|c|c|c|c|c|}
\hline \multirow{2}{*}{ Phase } & \multirow{2}{*}{ 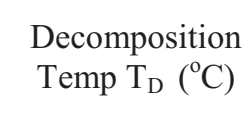 } & \multicolumn{2}{|c|}{ Weight loss (\%) } & \multirow{2}{*}{ Decomposition phase } \\
\hline & & Observed & Calculated & \\
\hline I & $48.70-181.53$ & 20.04 & 21.03 & $\left(\mathrm{Cd}_{0.973} \mathrm{~Pb}_{0.027}\right) \mathrm{C}_{2} \mathrm{O}_{4} .3 \mathrm{H}_{2} \mathrm{O} \longrightarrow\left(\mathrm{Cd}_{0.973} \mathrm{~Pb}_{0.027}\right) \mathrm{C}_{2} \mathrm{O}_{4}+3 \mathrm{H}_{2} \mathrm{O}$ \\
\hline II & $278.80-372.33$ & 28.10 & 28.02 & $\left(\mathrm{Cd}_{0.973} \mathrm{~Pb}_{0.027}\right) \mathrm{C}_{2} \mathrm{O}_{4} \longrightarrow\left(\mathrm{Cd}_{0.973} \mathrm{~Pb}_{0.027}\right) \mathrm{O}+\mathrm{CO}+\mathrm{CO}_{2}$ \\
\hline
\end{tabular}

Table 5. TG profile of LMCO crystals.

\begin{tabular}{|c|c|c|c|c|c|}
\hline Chemical formula & $\begin{array}{c}\text { Molecular } \\
\text { weight }\end{array}$ & Phase & $\mathrm{T}_{\text {DTG }}\left({ }^{\circ} \mathrm{C}\right)$ & $\mathrm{T}_{\text {DSC }}\left({ }^{\circ} \mathrm{C}\right)$ & $\begin{array}{c}\text { Molecule } \\
\text { decomposed }\end{array}$ \\
\hline$\left(\mathrm{Cd}_{0.973} \mathrm{~Pb}_{0.027}\right) \mathrm{C}_{2} \mathrm{O}_{4} .3 \mathrm{H}_{2} \mathrm{O}$ & 257.03 & $\mathrm{I}$ & 135 & 148 & $3 \mathrm{H}_{2} \mathrm{O}$ \\
$\mathrm{I}$ & $\mathrm{I}$ & 349 & 363 & $\mathrm{CO}_{2}$ \\
\hline
\end{tabular}

The Bragg's diffraction pattern of LMCO crystals is shown in Fig. 6 for specific $2 \theta$ values. The sharp well defined peaks illuminated high crystalline nature of mixed crystal. Powder XRD pattern of the crystal was studied using PowderX software and indexed using N-TREOR09 program. After refinement with Chekcell 
software, the $d$-spacing and lattice parameters were measured (Table 6). The observed miller indices were in agreement with the standard values [2,6]. LMCO crystal belonged to triclinic system ( $P 1$ space group).

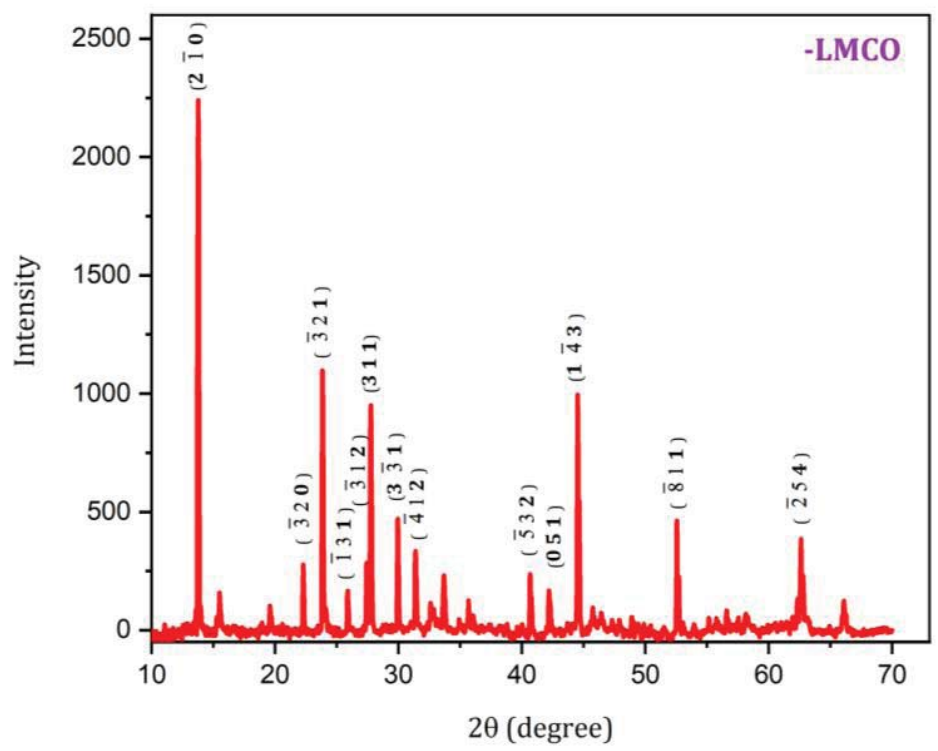

FIG 6. Powder XRD pattern of LMCO crystals.

Table 6. Cell parameters of LMCO crystals.

\begin{tabular}{|l|l|}
\hline Cell parameters & LMCO \\
\hline$A$ & $13.96 \AA$ \\
\hline$B$ & $11.79 \AA$ \\
\hline$C$ & $8.11 \AA$ \\
\hline $\mathrm{A}$ & $93.71^{\circ}$ \\
\hline $\mathrm{B}$ & $100.60^{\circ}$ \\
\hline$\Gamma$ & $102.23^{\circ}$ \\
\hline Space group & $P 1$ \\
\hline Geometry & Triclinic \\
\hline
\end{tabular}

Optical properties of LMCO crystal were investigated with the aid of UV-visible spectrum. The grown crystals were brought into solution form by dissolving $10 \mathrm{mg}$ of LMCO crystals in $1.5 \mathrm{~N}$ sulphuric acid heated to $80^{\circ} \mathrm{C}$ for 20 minutes. When crystal solution was irradiated with UV-visible light, showed absorbance in UV region with absorption maxima $\mathrm{A}_{\max }=1.79$ at $\lambda=204 \mathrm{~nm}$ (Fig. 7) and exhibited maximum transmittance in visible region. Tauc plot (Fig. 8) was developed to measure the band gap energy $\left(\mathrm{E}_{\mathrm{g}}\right)$. LMCO crystal possessed a band gap energy $\mathrm{E}_{\mathrm{g}}=5.57 \mathrm{eV}$ and behaved as insulator [7]. 


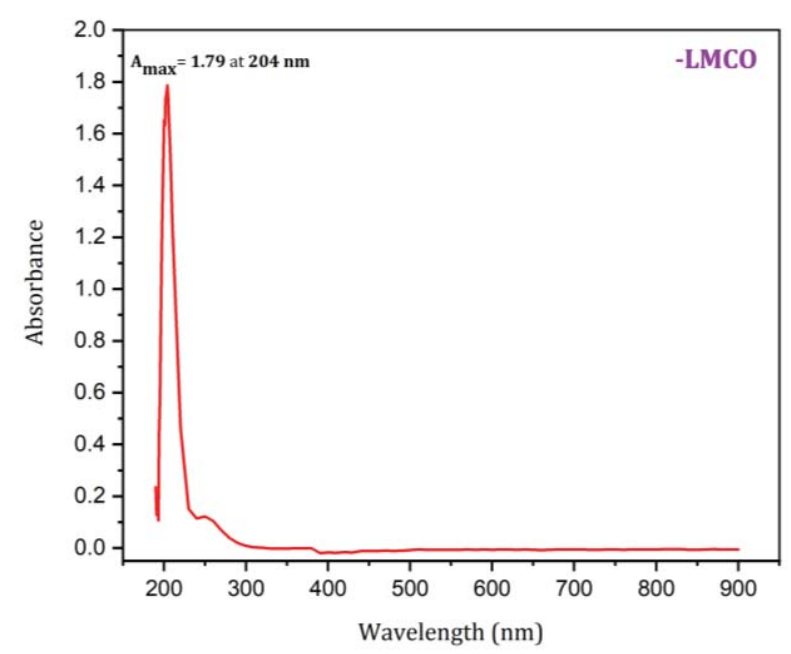

FIG 7. Absorption maxima of LMCO crystals.

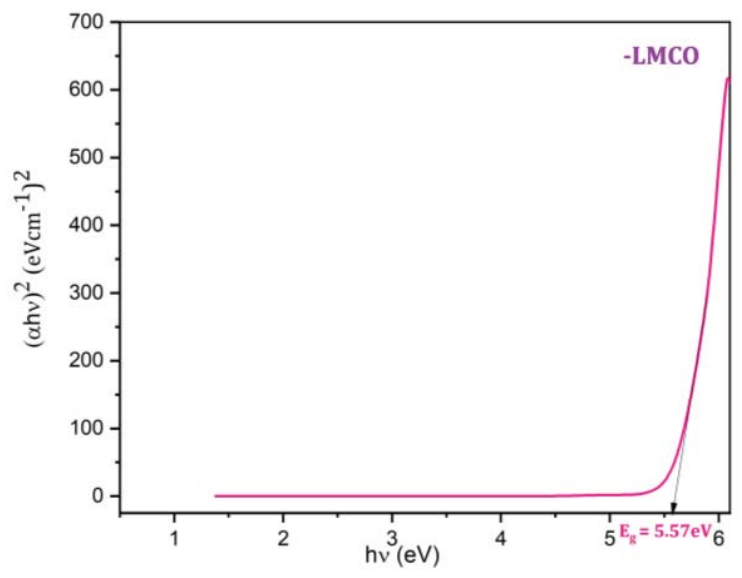

FIG 8. Band gap energy of LMCO crystals

\section{Conclusion}

LMCO crystals were successfully grown in oxalic acid impregnated silica hydro gel using single test tube diffusion technique. The grown mixed crystals were transparent, hard and water insoluble. EDX measurements confirmed the existence of $\mathrm{Cd}^{2+}$ and $\mathrm{Pb}^{2+}$ in 36.04:1 ratio. FTIR studies instigated $\mathrm{C}=\mathrm{O}$, $\mathrm{C}-\mathrm{C}, \mathrm{C}-\mathrm{O}, \mathrm{Pb}-\mathrm{O}, \mathrm{Cd}-\mathrm{O}$ and $\mathrm{OH}$ group in the crystal armature. $\mathrm{LMCO}$ crystal exhibited two decomposition phases in the temperature range $\left(48.70-372.33^{\circ} \mathrm{C}\right)$ and remained stable at $\mathrm{Cd}: \mathrm{PbO}$ state, possessed good thermal stability upto $1190{ }^{\circ} \mathrm{C}$. P-XRD measurements identified high crystalline nature and triclinic geometry with space group P1 for LMCO crystal. Overall, LMCO crystal possessed a molecular weight of 257.03 (chemical formula: $\left.\left(\mathrm{Cd}_{0.973} \mathrm{~Pb}_{0.027}\right) \mathrm{C}_{2} \mathrm{O}_{4} 3 \mathrm{H}_{2} \mathrm{O}\right)$; ingrained a band gap energy of $5.57 \mathrm{eV}$ and behaved as insulator. 


\section{Acknowledgments}

The authors are thankful to Backward classes welfare department, Government of Karnataka for financial support under Ph.D. fellowship scheme and grateful to USIC and DST-PURSE laboratory, Mangalore University, Karnataka and STIC laboratory, Cochin University, Kerala for providing laboratory facilities.

\section{REFERENCES}

[1] Patel A R and Venkateswara Rao, Bulletin of Materials Science 4, 527 (1982)

[2] Nagaraja Ponnappa, Jagannatha Nettar, Hema Mylnahalli, Delma D’Souza and Lokanath Neratur, Crystal Research and Technology 53, 1700261 (2018)

[3] Nagaraja K P, Pampa K J and Lokanath N K, Journal of Applicable Chemistry 7, 457 (2018)

[4] Jethva H O, Vyas P M, Tank K P and Joshi M J 117, 589 (2014)

[5] Rohith P S, Jagannatha N and Pradeepkumar K V, International Journal of ChemTech Research 13, 91 (2020)

[6] Delma D’Souza, Jagannatha N and Nagaraja K P, Journal of Applicable Chemistry 8, 1966 (2019)

[7] Mangala M Sanjeevannanavar, Jagannatha N and Rohith P S, Journal of Physics and Chemistry of Materials 7, $01(2020)$ 